NBER WORKING PAPER SERIES

\title{
WHY HAS ECONOMIC GROWTH SLOWED WHEN INNOVATION APPEARS TO BE ACCELERATING?
}

\author{
Robert J. Gordon \\ Working Paper 24554 \\ http://www.nber.org/papers/w24554 \\ NATIONAL BUREAU OF ECONOMIC RESEARCH \\ 1050 Massachusetts Avenue \\ Cambridge, MA 02138 \\ April 2018
}

This research was supported by the Smith-Richardson Foundation. I am grateful to Hassan Sayed for excellent research assistance, and to Ben Friedman, Joel Mokyr, and Isabel Sawhill, for helpful comments. The views expressed herein are those of the author and do not necessarily reflect the views of the National Bureau of Economic Research.

NBER working papers are circulated for discussion and comment purposes. They have not been peer-reviewed or been subject to the review by the NBER Board of Directors that accompanies official NBER publications.

(C) 2018 by Robert J. Gordon. All rights reserved. Short sections of text, not to exceed two paragraphs, may be quoted without explicit permission provided that full credit, including () notice, is given to the source. 
Why Has Economic Growth Slowed When Innovation Appears to be Accelerating?

Robert J. Gordon

NBER Working Paper No. 24554

April 2018

JEL No. D24,E24

\begin{abstract}
$\underline{\text { ABSTRACT }}$
Measured between quarters with identical unemployment rates, U. S. economic growth slowed by more than half from 3.2 percent per year during 1970-2006 to only 1.4 percent during 2006-16, and only half of this GDP growth slowdown is accounted for diminished productivity growth. The paper starts from the proposition that GDP growth matters, not just productivity growth, because slower GDP growth provides fewer resources to address the nation's problems, including faltering education, aging infrastructure, and the looming shortfall in funding for Social Security and Medicare, and it also implies lower net investment and a reduced rate at which new capital can embody the latest technology.
\end{abstract}

The paper documents the contribution to slower GDP growth of the separate components of demography -- fertility, mortality, life expectancy, and immigration. Particular emphasis is placed on the interaction between rising inequality and the slower secular rise of life expectancy in the U.S. compared to other developed countries, both in the form of a large gap in life expectancy between rich and poor, and the stagnation of life expectancy for the lowest income quintile. Further contributions to slowing growth are made by a decline in the population share of both legal and illegal immigration and a turnaround from rising to declining labor force participation. Rising inequality creates a gap between the growth of average real per-capita income relative to that of median real income, and alternative measures of the evolution of this gap are compared and assessed.

Causes of declining productivity growth begin with the slowdown in the rate of increase of educational attainment resulting from the interplay of demand and supply factors, including the flattening of the college wage premium and the rising relative price of college education. Why did productivity growth decline after 2006 despite an increase in the rate at which new U.S. patents were issued in 2006-16 compared to earlier decades? Part of the slowdown is attributed to the maturity of the IT revolution, which also helps to explain the trajectory of the college wage premium. Aspects of the productivity growth slowdown include the declining productivity of research workers, diminishing returns to drug innovation, and the evolutionary rather than revolutionary impact of robots and artificial intelligence, which are replacing workers slowly and only in a minority of industrial sectors throughout the economy. Also considered are alternative explanations of slower productivity growth, including low investment and mismeasurement.

\author{
Robert J. Gordon \\ Department of Economics \\ Northwestern University \\ Evanston, IL 60208-2600 \\ and NBER \\ rjg@northwestern.edu
}




\section{Introduction}

A central result of economic history is that there was very little economic growth prior to the First Industrial Revolution of the late eighteenth century. For instance, Stephen Broadberry and his co-authors (2015) after extensive research have documented a growth rate of per-capita income in Britain from 1270 to 1700 of only 0.2 percent per annum. Beginning around 1750 the rate of economic growth accelerated gradually for a variety of reasons that are concisely explained in Joel Mokyr's (2018) companion paper in this volume. Because economic historians usually define their subject matter as economic behavior prior to the most recent forty or fifty years, they have understandably devoted less attention to the deceleration of economic growth in the developed world that began in the 1970s and has become more pronounced in the past decade.

While this paper documents the decline in economic growth in Developed East Asia and in Western Europe, otherwise its focus is on the United States. The gradual rise in the pace of economic growth, followed by a sustained decline, is one of the most important facts in American economic history. More than half a century has passed since Solomon Fabricant, in his Introduction to Kendrick's (1961) magisterial compilation of data on output and inputs, called attention to the acceleration of productivity growth that began around 1920. "The change in trend that came after World War I is one of the most interesting facts before us. There is little question about it. ... the rate of growth of productivity witnessed by the present generation has been substantially higher than the rate experienced in the quarter-century before World War I" (Fabricant, 1961, p. xliii).

The decade of the 1960s, at the beginning of which Kendrick's book was published, turns out in retrospect to have been the last of the five remarkable decades in which overall U.S. GDP growth raced along at close to four percent per year and labor productivity advanced at close to three percent per year. ${ }^{1}$ The pace of advance has slowed in two phases, the first after 1970 and the second after 2006. Taken together the two phases have reduced the annual growth rate of real GDP from 3.7 percent during 1920-70 to a mere 1.4 percent during 2006-16. Regarding this epochal decline in growth, to borrow Fabricant's words, "there is little question about it."

Debates about the outlook for future U.S. growth are dominated by the speculations of optimists who herald the imminent arrival of a Fourth Industrial Revolution. This focus on the future of technology, however, takes a narrow view of the process of economic growth. Productivity growth depends not only on innovation but also on the rate of increase in physical and human capital. Demography and inequality determine the extent to which productivity growth trickles down to individuals and households. This paper starts from the proposition that GDP growth matters, not just productivity growth, because slower GDP growth provides

\footnotetext{
${ }^{1}$ All references to labor productivity in this paper refer to the total economy (that is, real GDP per total economy hours of work) rather than to the more frequently quoted data on productivity in the business sector.
} 
fewer resources to address the nation's problems, including faltering education, aging infrastructure, and the looming shortfall in funding for Social Security and Medicare.

We take a careful look at the recent growth-reducing components of demography including mortality and life expectancy -- and inequality that would hold back the future growth of well-being even if labor productivity were to grow at a constant rate. Life expectancy and inequality are of independent interest, as they are two of the four components of the enhanced index of consumer welfare developed recently by Charles Jones and Peter Klenow (2016). ${ }^{2}$ In addition we examine the slowing growth of educational attainment that has largely removed one of the main sources of productivity growth in the last century. These factors would depress real GDP growth even if the impact of innovation on productivity growth had remained constant. However, productivity growth has slowed by far more than can be explained by the waning contribution of education, from 2.8 percent per year during 1920-70 to 1.0 percent per year from 2006 to 2016.

The paper then moves beyond education to an assessment of other sources of slower productivity growth. Its aim is to explain the paradox that innovative activity as measured by patent issuance has been increasing while productivity growth has been slower in the past decade than in any decade of recorded American history. The paper does not argue that everything useful has already been invented but rather that the Third (digital) Industrial Revolution has reached a stage of maturity in which ongoing innovation has less impact on productivity growth than during the rapid growth decade of 1996-2006. The paper examines the likelihood that the economy is on the verge of an explosion of growth in robots and AI capability that will destroy jobs on a massive scale, and it assesses the role of possible explanations of disappointing productivity growth that go beyond the impact of innovation, namely low investment and output mismeasurement.

\section{The Two-Phase Growth Slowdown}

The ingredients of the slowdown in GDP growth since 1970 are displayed in Table 1. To focus on long-run trends and avoid any influence of the ups and downs of the business cycle, growth rates are calculated between years with roughly the same unemployment rate. ${ }^{3}$ The growth rate of real GDP decelerated modestly from 3.71 percent during 1920-70 to 3.17 percent during 1970-2006. As shown in column (4), this GDP growth slowdown of 0.54 percentage points reflected the 1.07 point drag from slower productivity growth partly offset by the 0.53 point acceleration in the growth of hours. The upturn of hours growth, in turn, reflected both the 0.36 point rise in growth of hours per person (caused largely by the rise of

\footnotetext{
${ }^{2}$ The other two are measured real consumption expenditures per capita and leisure time.

${ }^{3}$ The unemployment rate was 5.2 percent in 1920, 5.0 percent in 1970, and 4.6 percent in 2006 . To align closely with 2006, data for 2016 are taken from the fourth quarter, when the unemployment rate was 4.7 percent, rather than from the full year of 2016.
} 
female labor force participation) and the 0.17 point rise in population growth as the baby-boom generation entered the labor force.

The second phase of the slowdown in GDP growth occurred after 2006, from 3.17 percent for 1970-2006 to a mere 1.35 percent during 2006-16. The demographic impact of slowing growth in hours of work contributed more to the GDP slowdown than did the deceleration of productivity growth. The overall 1.82 point drop in GDP growth reflected both the 0.78 point reduction in productivity growth and the large 1.04 point decline in hours growth. Slower growth in hours was, in turn, due to a 0.62 point contribution of growth in hours per person and a 0.42 point contribution of population growth.

Table 1 displays an interesting contrast between the two-phase deceleration of growth in productivity and in output per person. As shown in columns (4) and (5), the first phase of the productivity growth slowdown of -1.07 percent was greater than the second-phase slowdown of -0.78 percent. In contrast for output per person the second phase deceleration of -1.40 percent was double the first phase drop of -0.71 percent. Overall, growth in output per capita exhibits a stunning seven-fold decline from 2.46 percent per year in 1920-70 to a mere 0.35 percent per year in 2006-16.

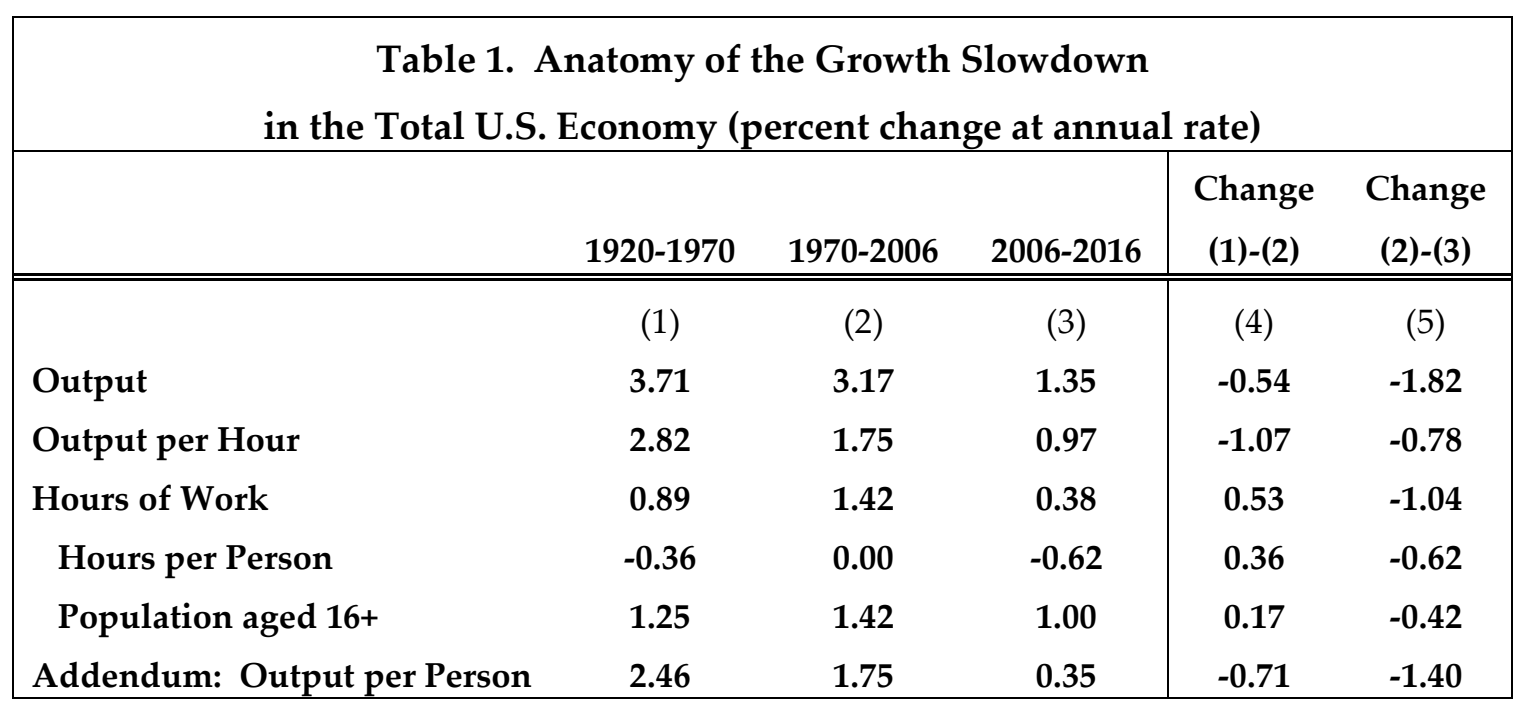

Source: Data for 1920, 1970, and 2006 are based on annual averages, while 2016 refers to 2016:Q4. Data for 1950-2016 for output is the average of Real GDP and Real GDI from the Bureau of Economic Analysis. Hours is an unpublished series on hours in the total economy obtained from the Bureau of Labor Statistics. Population aged 16+ is a published. BLS series. For 1920-50 output is BEA Real GDP linked in 1929 to Real GDP in Gordon (2012), Table A-1. Hours for 1920-48 are from Kendrick (1961), Table A-X. Population refers to the total population and is from the Historical Statistics, Table Aa7.

\section{Fertility, Mortality, Life Expectancy, and Immigration}

As shown in Table 1, a major source of the growth slowdown after 2006 is a sharp decline in the growth of hours of work. Fully 40 percent of this deceleration was contributed by 
a decline in population growth. Superficially population should be of no concern in the study of economic growth, which focuses on per-capita growth. But there are at least two channels by which slower population growth has an impact on individual well-being. First, slower growth in the number of new workers reduces net investment in new structures and machines that embody the latest technology. Second, with a fixed retirement age and increasing life expectancy, slowing population growth increases the dependency ratio of retired individuals to younger workers and implies an increased future fiscal burden of entitlement programs for the elderly.

Declining population growth reflects the combined influence of fertility, mortality, and immigration. The behavior of both fertility and mortality reveal emerging problems in U.S. society that I call "socioeconomic decay." From 2007 to 2015 the U.S. fertility rate declined from the replacement rate of 2.1 to a lower value of 1.8 as a reflection of an emerging set of obstacles faced by young Americans. ${ }^{4}$ This has in part resulted from a precipitous decline in the marriage rate for those aged 25 to 34 with a high school education or less from 85 percent in 1965 to only 45 percent in 2010. The marriage rate also declined for those with bachelor's degrees from 77 percent in 1965 to 52 percent in 2010. ${ }^{5}$ Among the causes are plant closings and wage stagnation that have eroded the ability of many men to hold steady well-paying jobs, and this has made them less attractive as marriage partners, while at the same time women have become more independent as opportunities for them have opened up in the labor market. The burden of student loan repayment is also a factor, forcing many college graduates to move back in with their parents, delaying household formation, marriage, and child rearing.

Population growth has also been reduced by a reversal for some groups of Americans in the historic trend of improved mortality rates. As shown in the recent work of Anne Case and Angus Deaton (2017), the mortality rate of white adults aged 35 to 54 with a high school or less education steadily increased from 1999 to 2015. Table 2 provides a comparison of sub-groups of the 50-54 age group within the U.S. with the same age group for all inhabitants of other selected developed nations. The authors contrast the experience of whites with a high school education and below, for which the mortality rate increased at an annual rate of 1.6 percent, and all whites with an increase at a rate of 0.5 percent, with the continuing progress toward lower mortality of blacks and Hispanics. This trend toward growing mortality among the less educated white Americans contrasts with steady progress toward lower mortality over the same 1999-2015 interval in ten European nations, Canada, and Japan.

\footnotetext{
${ }^{4}$ The source for the fertility rate is https://fred.stlouisfed.org/series/SPDYNTFRTINUSA.

${ }^{5}$ Marriage percentage data are from www.prb.org/Publications/Articles/2010/usmarriagedecline.aspx. The overall U.S. marriage rate per 1,000 has declined from 10.0 in 1985 to 6.9 in 2014, see https://www.cdc.gov/nchs/index.htm.
} 
Table 2. Annual Rate of Change of Mortality Rate for Age 50-54,

by U.S. Subgroups and Selected Other Nations, 1999-2015

\begin{tabular}{|lc|}
\hline & Percent per Year \\
\hline \hline U. S. Groups & \\
White Non-Hispanic High School or Less Education & 1.6 \\
White Non-Hispanic, All & 0.5 \\
Black Non-Hispanic & -2.3 \\
Hispanic & -1.5 \\
Ten European Nations & -2.1 \\
Canada & -1.1 \\
Japan & -2.2 \\
\hline
\end{tabular}

Source: Case and Deaton (2017), Tables 1 and 2. The ten European nations are Denmark, France, Germany, Ireland, Italy, Netherlands, Spain, Sweden, Switzerland, and United Kingdom.

The Case-Deaton analysis of the difference across U.S. groups and across nations highlights the role for U.S. whites with a high school education or less of what the authors label as "deaths of despair" that result from suicide and addiction to both opioid drugs and alcohol. Their analysis by birth cohort shows an increase in the death rate from drugs, alcohol, and suicide at age 35 from 30 per 100,000 for those born in 1960 to 110 per 100,000 for those born in $1980 .{ }^{6}$ The authors' assessment of causes emphasizes the steady deterioration since the early 1970s of job opportunities for those with high school or less education, the same employment problems cited above that play a role in the decline of marriage - plant closings as a result of globalization, layoffs that occur when machines replace workers, and wage reductions as unions fade away.

The mortality experience of U.S. whites in the last 15 years is echoed by the evolution of life expectancy over a longer period. Table 3 displays for selected years since 1961 life expectancy at birth for the U.S., EU-15, Canada, and Japan (the "EU-15" refers to the 15 member countries in the European Union prior to its enlargement in 2004). The first column shows that in 1961 life expectancy for the U.S. was longer than in the EU-15 and Japan, while slightly behind Canada. But steadily over the years the improvement in life expectancy in the U.S. has been slower than that of the other countries, so that by 2015 life expectancy in the U.S. was fully 4.0 years shorter than the average of the other countries. In 2015 life expectancy in the U.S. actually declined by 0.1 year from 2014, at least temporarily reversing decades of progress.

\footnotetext{
${ }^{6}$ The birth cohort comparison comes from Case-Deaton (2017), Figure 7, while the death rates from drugs, suicide, and alcohol come from their text and from their Figure 11.
} 


\begin{tabular}{|lrrrr|}
\hline \multicolumn{5}{|c|}{$\begin{array}{c}\text { Table 3. Life Expectancy at Birth in the United States, } \\
\text { Western Europe, Canada, and Japan, 1961-2014 }\end{array}$} \\
\hline & 1961 & 1980 & 2000 & 2015 \\
\hline \hline United States & 70.3 & 73.6 & 76.6 & 78.7 \\
Western Europe (EU-15, Population-weighted) & 70.0 & 73.8 & 78.4 & 82.2 \\
Canada & 71.4 & 75.1 & 79.2 & 82.1 \\
Japan & 68.3 & 76.1 & 81.1 & 83.8 \\
U.S. minus average of EU, Canada, Japan & 0.4 & -1.4 & -2.9 & -4.0 \\
\hline
\end{tabular}

Life Expectancy Source: http://data.worldbank.org/indicator/SP.DYN.LE00.IN

Source for Population Weights: https://www.conference-board.org/data/economydatabase/index.cfm?id=27762

EU-15 nations include those listed in Table 2 plus Austria, Finland, Greece, Luxembourg, and Portugal.

The slow rate of progress of American life expectancy reflects in part a growing bifurcation between the death rates of those at different levels of income and education. Male life expectancy at age 50 for the bottom income quintile was 26.6 years for those born in 1930 and a lower 26.1 years for those born in 1960. For the top income quintile the respective life expectancies were 31.7 and 38.8 years. Thus the gap in life expectancy between the top and bottom quintile grew from 5.1 years to an enormous 12.7 years. An implication is a large and growing inequity in the number of years that the different income groups are alive to collect Social Security and Medicare benefits. ${ }^{7}$

In addition to fertility and mortality, population growth also depends on immigration, and this has become another source of slowing population growth. Taking legal and illegal immigration together, the annual increase in the number of foreign-born individuals living in the U.S. has declined from 1.1 million during 1990-2000 to 630,000 in 2010-16, or from 0.37 percent of the population to just 0.20 percent (Frey, 2017, Table 1). Tougher border enforcement and a declining birth rate in Mexico have reduced the number of illegals who try to enter the United States, while high unemployment in the U.S. during 2009-14 as well as improving economic conditions in Mexico have stimulated a return flow of illegals from the U.S. back to Mexico. This return flow has been augmented by those subject to forced deportation. The decline of immigration from Latin America is demonstrated by the surprising fact that between 2010 and 2016 fully 58 percent of the increase in the foreign-born population has come from Asia (Frey, 2017, Figure 2).

\footnotetext{
${ }^{7}$ See The Growing Gap (2015), Figure 3-2, p. 52. On the implications for benefits recipients and benefits reform, see Auerbach et al. (2017).
} 


\section{Labor Force Participation}

Referring back to Table 1, growth in hours of work has slowed not just because of a decline in population growth but also because of a decline in hours worked per member of the population. Most of this reflects a turnaround in the labor force participation rate (LFPR), which rose from 58.8 percent in 1965 to a peak of 67.1 percent in the interval 1997-2000 and then fell in stages to 66.0 in 2007 and then to 62.8 percent in 2015-2017. ${ }^{8}$ Of this 3.2 percentage point decline from 2007 to 2017, fully 2.5 percentage points can be attributed to the aging of the U.S. population, as the baby-boom generation born in 1946-64 makes its transition from work to retirement (Eppsteiner et al., 2017). ${ }^{9}$

The remaining 0.7 percentage points of the post-2007 decline in the LFPR is attributable primarily to a lower LFPR for prime-age men (those aged 25 to 54 ), particularly those with a high school education or less. This decline reflects in large part the loss of stable middle-income employment opportunities that was cited earlier in connection with the falling marriage rate and the "deaths of despair." Lower participation for prime-age men continues a long downward trend that has taken their LFPR from 98 percent in the 1950s to 88 percent today; for those with a high school education or less the LFPR has fallen to 84 percent. ${ }^{10}$ One explanatory factor is drug use, which causes many job applicants to fail drug tests and others to fail to apply because they know they cannot pass the drug tests. ${ }^{11}$

Among 20 developed OECD countries, the U. S. prime-age male LFPR is the second lowest, ahead only of Italy. The U.S. prime-age female LFPR is the third lowest, ahead only of Ireland and Italy. ${ }^{12}$ After duplicating the rise of the U.S. prime-age female participation rate through the late 1990s, the Canadian rate continued to rise to 82.2 percent by 2016 in comparison to the U.S. rate of 74.3 percent. Why? Canada's federal government encouraged more two-earner families by cutting tax rates, adding support for child care, and expanding paid parental leave. In contrast, the U.S. government spends relatively little to subsidize child care and has no national paid family-leave program (Leubsdorf (2017). Higher prime-age male

\footnotetext{
${ }^{8}$ Civilian LFPR for the total population and for prime-age adult males are from FRED.

${ }^{9}$ An alternative estimate by Aaronson et al. (2014), Table 1, attributes 46 percent of the decline through mid-2014 to aging. The difference with the Eppsteiner et al. (2017) estimate is partly due to the three years of additional data available to the latter study, as during those three years the remaining cyclical component of the decline in the participation rate largely or entirely disappeared.

${ }^{10}$ The 84 percent participation rate for prime-age males with a high-school education or less is from Black et al. (2016), Figure 4.

${ }^{11}$ Many examples of failures to pass drug tests by applicants with and without high school diplomas are provided by Schwartz (2017).

${ }^{12}$ The OECD data come from https://stats.oecd.org/Index.aspx?DataSetCode=LFS SEXAGE 1 R\#
} 
participation in other countries reflects in part greater government support for retraining and moving of workers who experience prolonged spells without employment.

Even if there is no further decline in the prime-age participation rate, the prospects for future growth in the labor force stand in sharp contrast to the rapid pace that underpinned economic growth during 1970-2006. Actual labor force growth was 1.68 percent per year in 1970-2006, only 0.50 percent in 2006-16, and annual growth in the population aged 18-64 over the next 25 years is projected by the U.S. Census Bureau to be only 0.38 percent. ${ }^{13}$ Thus labor force growth alone has shaved more than one full percentage point off attainable future U.S. output growth as compared to 1970-2006, both in terms of actual labor force behavior since 2006 and the prospective outcome over the next 25 years.

\section{The Impact of Rising Inequality on Income Growth}

The output growth rates in Table 1 are averages over the entire population and do not take account of the fact that a disproportionate share of income has been flowing to the top of the income distribution, particularly the top one percent. When income growth is skewed, the growth in median income falls short of the growth of average income. The most frequently cited measure of this shortfall comes from the work of Thomas Piketty and Emmanuel Saez (2003), hereafter P-S. Their data do not allow a comparison of median versus average income growth, but they do provide average income data for the bottom 90 percent of the income distribution that can be compared with average income of the entire population. As shown in Table 4, line 1b, from 1970 to 2014 the average annual growth rate of real income in the bottom 90 percent was actually a negative 0.12 percent as compared to 0.56 percent for the total, a shortfall of 0.68 percent per year. ${ }^{14}$

A direct comparison of mean and median real household income growth is provided by the Census Bureau, as shown in section 2 of Table 4 . The gap between mean and median income was 0.58 percent during 1970-2000 and then fell to 0.26 percent during 2000-2014., for an average of 0.47 percent over 1970-2014. This was somewhat less than the 0.68 gap in the P-S data for the same period, reflecting many definitional differences between the two sources. What is notable in both data sources is the turnaround in both mean and median income growth (average vs. 0-90 for P-S) from positive before 2000 to negative over the 2000-2014 interval.

\footnotetext{
${ }^{13}$ Actual civilian labor force growth for the years 1970, 2006, and 2016 is from FRED. Population projection for 1864 age group over 2015-2040 comes from Table 3 in https://www.census.gov/data/tables/2014/demo/popproj/2014-summary-tables.html .

${ }^{14}$ The growth rate for the bottom 99 percent was 0.31 percent, for a gap compared to the average of all income earners of 0.35 percent.
} 


\section{Table 4. Annual Growth Rate of Real Income by Income Group, Alternative Sources, 1970-2014}

\section{Piketty-Saez, Taxpayer}

Units
a. Average 0-100
1.12
$-0.65$
0.56
b. Average 0-90
0.29
$-0.98$
$-0.12$
c. Gap
0.84
0.33

0.68

\section{Census Households}
a. Mean
1.22
$-0.26$
0.75
b. Median
0.65
$-0.52$
0.28
c. Gap
0.58
0.26
0.47

3. Piketty-Saez-Zucman Pre-tax, Individuals Aged 20+
a. Average 0-100
1.63
0.58
1.30
b. Average 0-90
1.10
0.17
0.80
c. Gap
0.54
0.41
0.50

4. Piketty-Saez-Zucman Post-Tax, Individuals Aged 20+
a. Average 0-100
1.63
0.58
1.30
b. Average 0-90
1.26
0.33
0.97
c. Gap
0.37
0.25
0.33

Sources: Piketty-Saez (2003), calculated from online appendix available at https://eml.berkeley.edu/ saez - U. S. Census Bureau (2016), Table A1.

Piketty-Seaz-Zucman (2016), online Appendix Tables TB3 and TC3, from https://eml.berkeley.edu/ saez.

Both the P-S and Census data have serious flaws for comparisons of mean and median income over time. Both are on a pre-tax basis and ignore the impact of progressive taxation and 
government transfer payments, including food stamps and in-kind medical services. The P-S income data are expressed per taxpayer unit and ignore changes over time in the number of individuals in a taxpayer unit. Similarly, the Census data are per household and ignore the secular decline in the number of individuals per household. Fortunately, an ambitious new study by Piketty, Saez, and Zucman (2016), hereafter P-S-Z, addresses these and other inadequacies of past research on top incomes. Their unit of observation is the individual aged $20+$ rather than the tax-paying unit or household. In contrast to past studies that capture only about 60 percent of national income, theirs allocates to individuals all of national income including fringe benefits and capital income. They calculate distributional shares of both pretax income and income after all taxes and transfers, allocating not just government transfers but also the burden of all taxes and benefits of all government spending on goods and services, such as defense and police protection, to particular individuals.

The P-S-Z results for 1970-2014 are shown in sections 3 and 4 of Table 4 . The most important impact of their improved methodology is to raise substantially the growth rate of real income of all groups in all periods. Real income growth is no longer negative during 2000-2014. The P-S-Z gap for pre-tax income between the growth of average incomes and the 0-90 group is 0.50 percentage points over the full period, about the same as the Census result. The gap for post-tax income is a smaller 0.33 percentage points over the full period. Back in Table 1 we learned that real GDP per capita grew at only 0.35 percent per year during 2006-16, little different than the P-S-Z gap between average and 0-90 income growth, implying that real GDP per capita earned by the bottom 90 percent was virtually constant during the most recent decade.

Will income inequality continue to rise? While the most rapid increases in the pay of top executives, including greater reliance on stock options, occurred in the 1980s and 1990s, the annual P-S-Z gap between average and 0-90 incomes was still 0.25 percent in the period since the year 2000. An ominous predictor of future growth of inequality is the lack of intergenerational mobility in the United States as compared to some other nations. Alan Krueger (2015) has christened as "The Great Gatsby Curve" a relationship between income inequality and the equality of opportunity. He and other authors have shown that there is a tendency for nations like the U.S. with relatively high income inequality in one generation to exhibit a high correlation between the income level of parents and the economic status of their children when they become adults.

There are several complementary mechanisms for the relationship between high inequality and low intergenerational mobility. Higher income parents can provide better educational opportunities in the form of books, computers, high-quality day care, private schools, tutoring, and tuition support for high-cost selective colleges. Because high income parents are more likely to be married, they provide more interaction within the family than lowincome single parents, and this helps to account for the large vocabulary gap between children from high-income and low-income families that has already emerged by the time they enter kindergarten. Further, high-income parents have better access to social networks that can 
provide summer internships and access to jobs in high-paying firms. Gary Becker and Nigel Tomes generalize these connections as "the learning, skills, goals, and other 'family commodities' acquired through belonging to a particular family culture" (1979, p. 1158). The lack of intergenerational mobility points to future increases in inequality, as the advantages of the children of parents at the top have a compounding effect on their future incomes, while the disadvantages of children at the bottom cause them to fall even further behind.

Evidence supporting the Great Gatsby Curve includes international evidence that contrasts the U.S. and U.K. at the extreme of high inequality and low mobility versus the Scandinavian countries which exhibit the opposite pattern (see Corak, 2013, Figure 1). When the very slow income growth since 2000 in the 0-90 percentile group, as shown in Table 4 above, is combined with low intergenerational mobility, the result is a steady decline in the prospect that children will earn more than their parents. Chetty et al. (2017) show that the fraction of children earning more than their parents (adjusted for inflation) has fallen from 90 percent for children born in 1940 to around 50 percent for children born in 1980, and that this decline is primarily caused by growing inequality rather than slowing aggregate income growth. The extent of backward movement in the most recent generation is related to the demoralization that in part lies behind the Case-Deaton (2017) phenomenon of "deaths of despair" discussed above in section 3 .

\section{Education and Productivity Growth}

So far we have examined sources of slowing growth in total output for reasons other than productivity growth, including the lower growth in population, the shrinkage of hours per person, as well as the rise of inequality and reduction of intergenerational income mobility. Now we are ready to turn to the sources of reduced productivity growth - Table 1 records a slowdown in the growth rate of U.S. labor productivity in the total economy by a factor of three, from 2.82 percent during 1920-70 to 1.75 percent during 1970-2006 to 0.97 percent during 200616. Before examining the role of innovation and technological change as sources of reduced productivity growth, we need to take into account the diminished growth contribution of educational attainment. Rising educational attainment is a fundamental source of productivity growth but has its own natural limits. Once everyone has completed high school, the contribution to productivity growth of higher educational attainment from that source is over. The same is true of college if there are limits to the share of the population who can complete a four-year college degree.

The history of U.S. educational attainment is one of a sharp kink around 1980 in the attainment trajectory. The annual growth rate of the percent of the population completing high school was 3.3 percent per year from 1915 to 1980 and only 0.2 percent from 1980 to 2016. The slowdown for four-year college percentage degree attainment had similar timing but was not as sharp, with an annual growth rate of 3.7 percent from 1915 to 1980 followed by a 1.3 percent 
growth rate from 1980 to $2016 .{ }^{15}$ The impact of high school and college completion taken together is provided by the number of years of educational attainment, which increased from 7.6 years in 1915 to 12.5 in 1980 to 14.0 in 2016, implying an annual growth rate of 0.8 percent from 1915 to 1980 followed by 0.3 percent from 1980 to $2016{ }^{16}$

The contribution of education to economic growth can be measured by calculating the growth in the efficiency of a worker-hour, and an efficiency index can be obtained by multiplying the average wage rate of people in each educational category by the percentage of the work force in that category. The growth in the efficiency index times labor's share of national income yields the education contribution to economic growth. Because of the slower movement of people to higher educational categories after 1980, the contribution as estimated by Goldin and Katz (2008, Table 1.3) declined from 0.41 percent for 1960-80 to 0.26 percent for 1980-2005. Subsequent work by Dale Jorgenson and co-authors (2017) projects the contribution to decline from an actual 0.25 percent contribution for 1990-2014 to a forecast contribution 0.10 percent for 2014-24. ${ }^{17}$

Both demand and supply factors raise the prospect of declining future growth in the percentage of young people who obtain four-year college degrees. On the demand side the demand for cognitive skills, which increased rapidly from 1980 to 2000, appears to have peaked. Paul Beaudry and co-authors (2016) document a large reversal in the demand for skill and cognitive tasks that appeared around 2000. As a result, workers with relatively high levels of skills and education have been displaced from cognitive tasks and forced into lower skilled jobs, and some of the low-skill workers previously in these jobs have been pushed out of employment and in some cases out of the labor force. Thus the Beaudry result helps to explain some of the decline discussed above in the LFPR for prime-age males. Robert Valletta (2016) provides results that support the Beaudry et al. interpretation of skill downgrading, showing that after rising rapidly from 1980 to 2000, the wage premium for college-educated workers grew by only a small amount between 2000 and 2010 and then was flat during the economic recovery from 2010 to 2015 . He also finds a decline in the wage premium between graduate degree holders and those without a graduate degree, a result in part of the growing imbalance between the rising supply of Ph.D. students and the declining number of tenured academic jobs. ${ }^{18}$

${ }^{15}$ High school and four-year college attainment for 1915 are taken from Goldin and Katz (2008), Figure 1.8, p. 34. Attainment data are available for selected years from 1940 to 2016 from National Center for Education Statistics Table 104.20, downloaded from https://nces.ed.gov/programs/digest/d16/tables/dt16 104.20.asp.

${ }^{16}$ Data on years of educational attainment for 1915, 1980, and 2005 are from Goldin and Katz (2008), Table 1.2. They are extrapolated to 2016 using the high school and college attainment percentages obtained from the NCES source cited in the previous footnote.

${ }^{17}$ See Jorgenson, Ho, and Samuels (2017), Figure 20. Exact numbers plotted in that figure are taken from the online data appendix, available at www.nber.org/chapters/c13695.

18 The declining career opportunities in academia are discussed by Belkin (2016). 
Examples abound of college-educated baristas and taxi drivers, and by one account the share of taxi drivers with a college degree increased from one percent in the 1970s to 15 percent in 2010. ${ }^{19}$ Abel et al. (2014) document that underemployment among college graduates, defined as holding a job that does not require a college education, has increased markedly among recent college graduates. While underemployment as a percent of all employed college graduates held steady at 33 percent for 35 year olds, the underemployment rate increased from 36 to 46 percent for 25 year olds between 2000 and 2009-11. This is consistent with the Beaudry research documenting the decline in the demand for cognitive skills.

The decline in the college wage premium and underemployment of college graduates are demand phenomena that interact with barriers on the supply side in the form of the rapidly rising cost of higher education and the increasing burden of student debt. From 1975 to 2015 the national accounts price of higher education increased at an annual rate of 7.1 percent in comparison to an inflation rate of 3.4 percent for all consumer expenditures. Expressed in real terms higher education is now 4.3 times as expensive as in 1975. While some of this price increase has been mitigated by scholarships, fellowships, and discounts, enough remains to cause outstanding student debt to quadruple to $\$ 1.34$ trillion between late 2003 and early $2017 .{ }^{20}$ Valletta (2016, p. 26) summarizes the demand-cost squeeze: “. . . the flattening of returns as costs have continued to rise suggests that college may be an unfavorable financial investment for rising numbers of individuals."

These demand and supply factors will depress the future growth of the percent of students completing four-year college degrees and thus the contribution of education to economic growth. But that is not the only channel from education to productivity growth. High student indebtedness impairs the credit rating of young graduates and makes it more difficult for them to raise the capital to start new firms, thus aggravating the long-term decline in the share of businesses that are newly formed. ${ }^{21}$ The relatively low scores of American 15year-olds in the OECD's 2015 international PISA tests reflect the poor preparation of high school students for technically demanding jobs - of the 35 members of the OECD U.S. students ranked $30^{\text {th }}$ in math and $19^{\text {th }}$ in science. ${ }^{22}$ As an example that happens all too often, when 10,000 applicants showed up recently for 800 job openings in a new Siemens plant in North Carolina, only 15 percent were able to pass a reading, writing, and math screening test geared toward a

\footnotetext{
${ }^{19}$ Vedder and Strehle (2017).

${ }^{20}$ Outstanding student debt from the Federal Reserve Bank of New York was $\$ 0.345$ trillion on December 31, 2003 and \$1.344 trillion on March 31, 2017. Downloaded from https://ycharts.com/indicators/us student loan debt

${ }^{21}$ On the links between student debt and the formation of new businesses by recent college graduates, see Wasik (2017).

${ }^{22}$ PISA test rankings are from www.pewresearch.org/fact-tank/2017/02/15/u-s-students-internationally-mathscience/
} 
ninth-grade education (Selingo, 2017). Problems in American education that contribute to these low test scores include unequal elementary and secondary school funding based on property taxes, and the limited extent of preschool education. Among OECD nations the U.S. ranks $26^{\text {th }}$ in preschool preparation for 4-year-olds and 24 ${ }^{\text {th }}$ for 3-year-olds (Herman et al., 2013).

\section{The Role of Innovation in the Productivity Growth Slowdown}

The deceleration of productivity growth is not a feature unique to the U.S. but rather is even more pronounced in other developed economies. Table 5 displays for selected intervals the annual rate of productivity growth for Developed East Asia (the "Four Tigers" plus Japan), Western Europe, and the U.S. In Developed East Asia productivity growth fell almost by half after 1970 and then slowed by one percentage point after 1996 and by yet another percentage point after 2006. The Western European pattern exhibits a similar monotonic slowdown, except that Europe's productivity grew two percentage points slower than Asia's before 1970 and roughly one percentage point slower in each interval after 1970.

\begin{tabular}{|lcccc|}
\hline \multicolumn{5}{|c|}{ Table 5. Annual Growth Rate of Labor Productivity, } \\
Developed East Asia, Western Europe, and United States, 1950-2016 \\
\hline & $1950-1970$ & $1970-1996$ & $1996-2006$ & $2006-2016$ \\
\hline \hline Developed East Asia & 6.71 & 3.47 & 2.47 & 1.45 \\
Western Europe (EU-15) & 4.76 & 2.73 & 1.50 & 0.55 \\
United States & 2.61 & 1.50 & 2.38 & 0.93 \\
& & & & \\
\hline
\end{tabular}

Source: Asia and Europe are from the Conference Board Total Economy Data Base. Developed East Asia includes Hong Kong, Japan, Singapore, South Korea, and Taiwan. Western Europe refers to the same EU-15 nations listed in Table 3. U.S. is the same series as in Table 1, except 2016 refers to the full year rather than the fourth quarter.

The U.S. slowdown pattern in Table 5 starts from a lower starting point in 1950-70 and differs in that there was a temporary productivity growth revival during 1996-2006 that did not occur in Developed East Asia or Western Europe. Rapid productivity growth in Developed East Asia and Western Europe from 1950 to 1970 reflected both rebuilding from wartime destruction and a delay -- due to the war, Great Depression, and other interwar dislocations -in adopting inventions and innovations of the late nineteenth and early twentieth centuries that propelled U.S. productivity growth between 1920 and 1950. These intervals of unprecedented productivity growth can be attributed to the combined effect of what I have previously (2016) called the "Great Inventions" of the Second Industrial Revolution, including electricity and its spinoffs (light, portable and fixed machines, elevators, subways, consumer appliances, central heating and air conditioning); the internal combustion engine that made possible motor and air transport; entertainment and communication devices from the telephone to motion pictures, radio, and television; advances in chemicals, plastics, antibiotics, and the foundations of modern medicine; and the delivery of clean running water and removal of waste that did so 
much to cure infectious diseases and reduce infant mortality. These inventions affected every aspect of life for businesses and consumers, reduced toil, discomfort, and drudgery on the job and at home, and involved fundamental one-time-only changes in such basic dimensions of human life as location (from rural to urban), temperature (from alternating hot and cold to an even temperature all year round), and speed (from the hoof and sail of 1820 to the Boeing 707 of 1958).

As shown in Table 5, the U.S. postwar growth performance includes a temporary revival during the 1996-2006 decade. For reasons that are not well understood, the impact of the Third (digital) Industrial Revolution on productivity growth was concentrated in this decade for the U.S. but more spread out in time for Developed East Asia and Western Europe. Changes in business methods began in the 1960s with mainframe computers and accelerated after 1980 with the rapid diffusion of the personal computer. Repetitive retyping by secretaries and tedious library research were replaced by authors writing their own words directly on personal computers while doing research on the internet. Calculations that were formerly done one at a time on mechanical calculators could now be performed at lightning speed on spreadsheet software. Catalogs that consisted of drawers of file cards in libraries or huge books of pages in auto parts departments were replaced by electronic catalogs with their unlimited listing capacity and their ability to display the number of items in stock. Questionnaires, surveys, and ballots for voting all migrated from paper to electronic form. Google, Amazon, Wikipedia, and other marvels of the digital age had already reached their present form by 2006.

The end of the temporary U.S. productivity growth revival after 2006 reflects the maturation of the revolution in business methods made possible by the desktop, laptop, office software, and the internet. This interpretation is complementary to the analysis cited above of Beaudry et al. (2016), who focus on the decline in the demand for cognitive skills after 2000. They attribute this shift in the labor market to the maturity of the IT revolution:

The key idea is that the IT revolution ... can be seen as a General Purpose Technology (GPT) and, like all GPTs before it, it will eventually reach maturity. . ... At this maturity stage, there will be greater demand for cognitive tasks than before the technological revolution but we will see a reduction in demand for these tasks relative to the investment stage. We argue that the turn of the century is that approximate turning point from the investment to the maturity stage (2016, p. S200).

In our interpretation the Third (digital) Industrial Revolution generated a productivity boost of only a decade between 1996 and 2006, as contrasted to the five-decade (1920-70) interval of rapid productivity growth following the Second Industrial Revolution, because the earlier inventions had a more profound effect on every aspect of human existence. The digital revolution in contrast, while completely changing office procedures in all industries, had less impact on the everyday life of consumers or on industries involved with physical transformation, such as manufacturing, construction, 
mining, utilities, and transportation, as well as important industries in the service sector plagued by Baumol's cost disease, particularly education and health care.

What does the future portend? Mokyr (2018) predicts a horizon of technological wonders: "Based on rapidly improving scientific insights, technological breakthroughs have the potential to change life in the foreseeable future as much as it did so in the century and a half since the Civil War." For the sake of argument, let us define as 50 years the span of history that Mokyr can foresee. Using productivity growth as the metric of transformation, for cumulative change over the next 50 years to be as great as in the 150 years since the Civil War would require future annual productivity growth to be triple the roughly two percent growth rate achieved since 1865, or an astounding six percent per year. The next 50 years would have to bring us innovation as great as the Second and Third Industrial Revolutions combined, as important as electricity and all its spinoffs, internal combustion and jet engines, communication from Bell's 1875 telephone to Jobs' 2007 smart phone, information from the typewriter to the laptop, indoor comfort achieved by central heating and air conditioning, not to mention urbanization, running water, indoor plumbing, the end of manual drudgery, and medical innovations from anesthesia, antiseptics, and antibiotics through CT and MRI scans to diagnose diseases and radiation and chemotherapy to treat it, not to mention knowledge of the death threat posed by smoking.

Contrary to Mokyr's assertion, I do not claim that everything important has already been invented. Rather, I am impressed by the frenetic pace of innovation while questioning the strength of its impact on productivity growth. The number of U.S. patents issued increased by 27.9 percent between 2006 and 2016, even faster than the 24.2 percent decadal increase from 1996 to 2006, which in turn was more rapid than the average 17.4 percent per-decade increase between 1956 and 1996. ${ }^{23}$ What explains the paradox of increasing inventive activity contrasted with the slowing productivity growth displayed in Table 5? One explanation is that it is becoming ever more resource-intensive to find ideas that have a major impact. Bloom et al. (2017) document a sharp decline in the productivity of research workers in information technology, agriculture, and medical research. In the context of Moore's Law that the density of computer chips doubles every two years, for instance, these authors document that the number of research workers to achieve the regular pace of this doubling has increased by a factor of 15 since the 1970s. Vijg (2011) emphasizes the sharply increasing cost of developing new drugs and the fact that most new drugs treat relatively rare conditions, while the most prescribed drugs for more common diseases were developed two or more decades ago.

A second explanation is that some categories of future innovation stressed by Mokyr are unlikely to boost productivity growth by the same order of magnitude as the transition from typewriters and card catalogues to the personal computer and internet. Among these are advances in molecular biology, new materials, and renewable energy. For instance, solar panels

\footnotetext{
${ }^{23}$ Data refer to utility patents and are taken from https://www.uspto.gov/web/offices/ac/ido/oeip/taf/issuyear.htm
} 
and wind towers reduce the manpower needed to generate electricity while maintaining or increasing the labor input needed to distribute electricity and repair transmission lines. Instead, in discussing the productivity impact of future innovations, it is more helpful to focus on four categories which offer the prospect of productivity enhancement -- 3-D printing, autonomous vehicles, robots, and artificial intelligence - and to consider a horizon of 25 years over which forecasts are more feasible than over 50 or 100 years. Progress thus far suggests that the impact on productivity growth and job destruction will be gradual and evolutionary, not sudden and revolutionary.

For instance, consider 3-D printing, also called additive manufacturing. It began as a more efficient way to create models and prototypes, and is now increasing its capabilities rapidly in such varied applications as the creation of dental crowns and aircraft engine manufacturing. But it is inherently more suited for small batch processing rather than mass production capable of producing, for instance, 17 million motor vehicles per year.

Driverless vehicles are not yet ready to replace the jobs of human taxi and truck drivers, according to a recent evaluation by Consumer Reports, because software and detailed 3-D maps have not yet been developed that will allow autonomous vehicles to navigate unmarked rural roads in the dark or make their way without human assistance through parking lots or driveways. Weather is a concern, as snow can cover up lane markers. "A self-driving car's software has to be ready for even the most bizarre circumstances and be ready to temporarily violate traffic laws - say, if a police officer waves the car into oncoming traffic lanes to avoid an obstacle. Could a car know to stop at a green traffic signal to avoid hitting a person chasing their dog into the street?" 24 The job classification most likely to be replaced first by autonomous vehicles is the long-distance truck driver, whereas intra-urban truck drivers carrying parcels to homes and businesses, as well as bread, beer, and soft drinks to supermarkets, have a dual function of driving and unloading. Replacing the truck's driver does not eliminate the need for humans to deliver its contents to the front porch, mail room, or supermarket shelf.

Over the next two decades are robots likely to be able to hop on and off trucks, delivering parcels? Robots are nothing new but rather were first introduced in manufacturing in 1961. By the 1990s robots were welding auto bodies and had taken over the auto paint shop. Robots move shelves in Amazon warehouses to humans who pick out objects from the shelves and pack them. But thus far robots have made few inroads outside of manufacturing and warehouses. In my daily life I regularly play a game called "find the robot," but there are no robots to be seen so far in retail stores, restaurants, construction sites, hotels, commercial aircraft, hospitals, or the offices I visit of doctors, dentists, and veterinarians, not to mention of fellow professors. Part of the problem with robots is that they are not yet adept at many of the routine tasks performed by humans, including hopping off trucks to deliver packages:

24 "Driverless Cars," Consumer Reports, May 2016, p. 49. 
An interesting reality check took place in June [2015], when two dozen teams of leading robotics engineers gathered in Pomona CA for a competition sponsored by the Pentagon's research agency. Their robots had to do simple tasks - walk up steps, turn a valve, operate a power drill. The chores would take a human five minutes, or 10 at most. The winning robot took 45 minutes. Most struggled badly, falling down steps and taking long pauses to figure things out, even with remote control assistance. Turning a knob to open a door proved daunting for many (Lohr, 2015).

Substantial progress is being made in the area of artificial intelligence, known as AI, with computer-assisted applications such as voice recognition and language translation. But AI is nothing new, and its applications thus far do not suggest a revolutionary boost to productivity or mass destruction of jobs. For instance, every time someone calls customer service and is asked by a computer voice to speak an answer, that person is encountering the voice recognition capabilities of AI. Every time that Amazon after a book sale provides photos of book covers of books "you also would like", Ai is in operation. Indeed, every transaction at the web sites of Amazon, airlines, or hotels represents the application of AI, so rather than being something new, AI has been replacing human jobs for at least two decades.

So far, however, $\mathrm{AI}$ is on course to replace human jobs in a steady, evolutionary way rather than in a sudden revolution. Many jobs of customer service agents, including most travel agents, have already been replaced by AI, while jobs for young lawyers have become scarcer as computers prove to be adept at carrying out searches for legal precedents. Similarly, computers are developing advanced skills in radiology diagnostics, although so far they are mainly working alongside radiologists rather than replacing them outright. As an indication of the slow pace of introduction of AI into business operations, a group of leaders from major corporations were polled by McKinsey Quarterly in 2016 and indicated that big data and advanced analytics had so far raised revenue or reduced cost by less than one percent. ${ }^{25}$

Some optimists like Erik Brynjolfsson and Andrew McAfee (2014) proclaim that we are on the verge of a Fourth Industrial Revolution, bringing with it unprecedented growth in productivity but also the danger of massive job destruction. The most vocal of the job alarmists are the Oxford economists Carl Frey and Michael Osborne (2017), who in 2013 predicted that over the next 20 years 47 percent of all American jobs would disappear. Yet in the four years since they first issued their warning, the American economy has created 10.1 million new jobs. ${ }^{26}$ A look at the Frey-Osborne list of disappearing jobs reinforces the implausibility of their forecast. For instance, they predicted that 55 percent of all airline pilot jobs will disappear, but the Federal Aviation Administration has not even begun to consider allowing commercial airline flights to be flown with a single pilot. Despite the inroads of Amazon, e-commerce still

\footnotetext{
${ }^{25}$ Article from McKinsey Quarterly, January 2015, quoted by Bresnahan and Yiu (2016).

${ }^{26}$ This is the difference in nonfarm payroll employment between June, 2013 and June, 2017. Data from FRED.
} 
accounts for only 8.5 percent of retail trade, yet Frey and Osborne predict that by 2033 fully 92 percent of retail sales jobs will have disappeared along with 86 percent of those of real estate agents. ${ }^{27}$

\section{Alternative Interpretations}

The diminished impact of ongoing innovation is the primary cause of the monotonic decline in productivity growth in Developed East Asia and Western Europe over the intervals displayed in Table 5, as well as the slump in U.S. productivity growth since 2006 after the temporary digital-spurred revival of the late 1990s and early 2000s. Two other widely cited causes are weak investment growth, and mismeasurement of output and productivity growth.

Investment. Measured as a share of the business capital stock, net investment in the U.S. economy has exhibited a steady decline from an average of 3.45 percent during 1950-86 to 2.60 percent during 1987-2007 and then, skipping the recession years of 2008-09, a further decline to a mere 1.50 percent during 2010-15. This would appear to make slumping investment a prime suspect as a cause of the productivity growth slowdown. Indeed, if capital input is productive, then slowing net investment must reduce productivity growth. But a compelling case can be made that the causation also runs in reverse from slowing GDP growth to slumping investment. It has been a central tenet of growth theory since Solow (1957) that in equilibrium the capital-output ratio is constant. It follows, therefore, that the long-run decline in GDP growth due to slower growth in population and hours per person would lead to a decline in the growth rate of capital and hence a decline in net investment. In addition slow growth of productivity for any reason other than investment itself would feed back into slower growth of capital and lower net investment. This passive role of net investment, responding to feedback from other sources of slower output growth, is a basic element in the analysis of slow recent economic growth by Fernald et al. (2017) and in the growth forecasts of Jorgenson et al. (2017).

Mismeasurement. Several recent papers have looked at the hypothesis that the slowdown of U.S. productivity growth after 2006 is an illusion due to faulty measurement. Attention has been divided between the business sector and the role of recent inventions in creating consumer surplus. Regarding business sector productivity, we noted in Table 5 that U.S. productivity growth alternated across time intervals between rapid and slow. But measurement methods, particularly the methods of adjusting price indexes for new products and quality change, have been relatively constant. Two decades ago the Boskin Commission (1997) concluded that the Consumer Price Index was biased upward by 1.1 percent per year, and measurement methods in the official price indexes have been steadily improved since then, as described in detail by Moulton (2017). Using the numbers for the U.S. in Table 5, it is implausible to argue that measurement became worse after 1970 by enough to reduce productivity growth by 1.11 percentage points and then became better after 1996 by enough to

${ }^{27}$ E-commerce as a percent of total retail sales in the first quarter of 2017 was 8.5 percent, according to FRED. 
raise productivity growth by 0.88 points and then became worse again after 2006 by enough to reduce productivity growth by 1.45 points.

Byrne et al. (2016) focus on the slowdown in business productivity growth after 2004 and conclude that measurement bias has become smaller rather than more important, because there has been a steady upward bias in the prices of information and communication technology (ICT) equipment, while the GDP share of production of ICT equipment fell after 2004, thus reducing the importance of this ongoing bias as a cause of slower growth of GDP and labor productivity. Further, the share of ICT equipment that was imported increased sharply after 2004 and, because ICT import price indexes are upward biased, a correction for that bias raises the growth of ICT imports, raises the growth of ICT investment and capital, and thus reduces the growth rate of total factor productivity. ${ }^{28}$ These authors conclude that correction of price index bias causes a measurement improvement of 0.31 points per year, so that correctly measured labor productivity growth slowed down even more than the official measure.

A different source of measurement error has been identified by Guvenen et al. (2017), who document the increasing importance of profit-shifting by U.S. multinationals that causes part of their economic activity to be attributed to their foreign affiliates, leading to an understatement of U.S. GDP. The resulting understatement of U.S. productivity growth is estimated at 0.1 percent per year for 1994-2004, 0.25 percent per year for 2004-2008, and zero for 2008-2014. By boosting productivity growth in the rapid productivity era of 1994-2004, their research adds to the extent of the slowdown since 2008.

Official statistics have failed to place any value on the invention of the smart phone and tablet, which have achieved ubiquity in the past decade. But their primary use is for consumers rather than as a tool to boost business productivity. Social networking on Facebook, game playing, watching YouTube videos, and trading of digital photos do not generate business output that allows firms to create jobs or raise wages. To be sure, there are growing uses of smartphones and tablets in business settings, including the smartphones of Uber drivers, the tablets carried by home repair workers and airline pilots, and as devices for ordering and payment in some fast food and casual restaurants. But mainly the smart phone produces consumer surplus that is not included in GDP nor in the productivity statistics. This is nothing new. Consumer-oriented inventions have always created benefits to consumers that have not been included in GDP, including many of the great inventions of the 1870-1970 era.

How large is the consumer surplus benefit of these new devices and free internet services more generally? Syverson (2017) surveys several approaches. While most of the literature that he reviews implies consumer surplus estimates that would offset less than 0.1

\footnotetext{
${ }^{28}$ The import share was 17.8 percent in 2002 and 87.9 percent in 2011-13. The correction of the upward bias in the import deflator does not change GDP growth, because faster import growth is subtracted and faster investment growth is added. Total factor productivity growth declines because it subtracts from unchanged GDP growth both unchanged labor input growth and faster capital input growth.
} 
percentage point of the post-2006 productivity growth slowdown, he updates a plausible approach that implies a consumer surplus estimate large enough to offset fully 0.6 percentage points. Recall that half of this is offset by the Byrne et al. (2016) estimate for the business sector that productivity growth has slowed down by 0.3 percentage points more than in the official data.

For comparisons of the rate of improvement of consumer well-being contributed by free internet services with earlier eras, we would need to estimate the value of consumer surplus of previous inventions, such as the many innovations that benefitted consumers between 1870 and 1970. These included the enormous consumer surplus provided by electric light, refrigeration and air conditioning, the replacement of scrub boards by automatic washing machines, the replacement of horses by motor cars, the replacement of water pails by running water and of outhouses by waste removal pipes, the replacement of carrying wood and coal for heat by central heating fueled by natural gas, the arrival of free entertainment on radio and TV, and the conquest of infectious diseases and infant mortality. The value of these improvements to every aspect of human life would surely outweigh the importance of free internet services that arrived during 2006-16. This added value would thus amplify rather than diminish the contrast between the 2.46 percent growth rate of output per person achieved during 1920-70 in Table 1 above relative to the 0.35 percent growth rate of 2006-16.

\section{Conclusion}

Comparing the interval 2006-16 with 1970-2006, real GDP growth fell by 1.82 percent per year, and less than half of this was due to slowing productivity growth. About 40 percent of the remainder was due to the decline of population growth as a result of falling fertility, rising mortality for some groups, a slower improvement in life expectancy than in other developed nations, and declining immigration. The other 60 percent of declining GDP growth not attributable to the productivity slowdown was due to the turnaround in labor force participation from rising in the last quarter of the $20^{\text {th }}$ century to falling since 2000 , both because of the retirement of the baby boom generation and the decline in prime-age labor force participation.

A common thread is that job losses due to globalization and automation, together with rising inequality, have resulted in demoralization and diminished expectations. The declining ability of men to earn steady incomes has led to a decline in marriage, a postponement of household formation, a decline in fertility, and an increase in what Case and Deaton call "deaths of despair" due to suicide and addiction. Lower prime-age participation was due not only to plant closings but also the more general demoralization and drug addiction.

Rising educational attainment during the $20^{\text {th }}$ century was an important source of productivity growth, but the pace of that increase slowed markedly after 1980. Rising high school completion is no longer a source of growth, while the recent and prospective rise in the share of young people completing a four-year college degree has been slowed by a combination 
of declining demand and more costly supply. On the demand side there has been a leveling off in the demand for cognitive skills and of the college wage premium. On the supply side the rapid increase in the cost of higher education and growing indebtedness have caused some students to drop out and others never to attempt a four-year degree. Student indebtedness also feeds back into a lower rate of new business formation of young firms and a delay in household formation.

The secular decline in productivity growth has been shared by Developed East Asia, Western Europe, and the U.S., with the difference that the U.S. enjoyed a temporary productivity growth revival during 1996-2006 that does not appear in the data for the other two areas. The paper poses the paradox that inventive activity as measured by patents issued has been accelerating while productivity growth has slumped to the slowest growth rates of the industrial era. The commonality across developed nations of the productivity slowdown adds plausibility to our preferred explanation of the paradox, that ongoing innovation in the past decade has had less impact in raising productivity growth than formerly. In the U.S. data the rapid productivity growth of 1920-70 reflects the importance and broad scope of the Great Inventions of the Second Industrial Revolution, and the temporary revival of 1996-2006 reflects the impact of the Third (digital) Industrial Revolution. But the transformative change in business methods made possible by the digital revolution was largely over by 2006. Prospective innovations over the next two decades, including 3-D printing, autonomous vehicles, robots, and artificial intelligence are likely to evolve gradually rather than suddenly causing a sharp jump in productivity growth or a massive loss of jobs.

While declining net investment is also a cause of slowing productivity growth, there is a concurrent channel of reverse causation in which declining population growth and labor force participation, together with the dampened impact of innovation, erode the extent of profitable investment opportunities. Thus low net investment is both a cause and a result of the overall slowdown in GDP growth. Finally, recent research has concluded that mismeasurement is not a source of the post-2006 productivity growth decline in the business sector, and in fact that the properly measured slowdown is greater than in the official data. Estimates differ for the magnitude of the creation of unmeasured consumer surplus from free internet services, but in the context of long-run growth that benefit needs to be compared to the enormous amount of unmeasured consumer surplus created by the Great Inventions of the Second Industrial Revolution. 


\section{References}

Aaronson, Stephanie, Cagner, Tomaz, Fallick, Bruce, Galbis-Reig, Felix, Smith, Christopher, and Wascher, William (2014). "Labor Force Participation: Recent Developments and Future Prospects,” Brookings Papers on Economic Activity, Fall, 197-255.

Abel, Jaison R., Deitz, Richard, and Su, Yaqin (2014). “Are Recent College Graduates Finding Good Jobs?” Current Issues in Economics and Finance, Federal Reserve Bank of New York 20 (no. 1).

Auerbach, Alan J., and twelve co-authors (2017). "How the Growing gap in Life Expectancy May Affect Retirement Benefits and Reforms,” NBER Working Paper 23329, April.

Beaudry, Paul, Green, David, and Sand, Ben (2016). “The Great Reversal in the Demand for Skills and Cognitive Tasks,” Journal of Labor Economics 34 (June), S199-S247.

Becker, Gary S., and Tomes, Nigel (1979). “An Equilibrium Theory of the Distribution of Income and Intergenerational Mobility,” Journal of Political Economy 87 (no. 6), 115389.

Belkin, Douglas (2016). “Ph.D. Prospects Peter Out,” Wall Street Journal, June 15, A3.

Black, Sandra, Furman, Jason, Rackstraw, Emma, and Rao, Nirupama (2016). “The Long-term Decline in US Prime-Age Male Labour Force Participation,” VoxEU.org, July 6.

Bloom, Nicholas, Jones, Charles I, Van Reenen, John, and Webb, Michael (2017). “Are Ideas Getting Harder to Find?” Stanford research paper Version 0.8, July 11, download from web.stanford.edu/ chad/ideaPF.pdf

Boskin, Michael, Dulberger, Ellen R., Gordon, Robert J., Griliches, Zvi, and Jorgenson, Dale W. (1997). “The CPI Commission: Findings and Recommendations,” American Economic Review 87 (no. 2), 78-83.

Bresnahan, Timothy, and Yiu, Pai-Ling (2016). “Adoption of New Information and Communications Technologies in the Workplace Today,” NBER Working Paper 22356, June.

Broadberry, Stephen, Campbell, Campbell M. S., Klein, Alexander, Overton, Mark, and van Leeuwen, Bas (2015). British Economic Growth, 1270-1870. Cambridge: Cambridge University Press.

Byrne, David M., Fernald, John G., and Reinsdorf, Marshall B. (2016). "Does the United States Have a Productivity Slowdown or a Measurement Problem?” Brookings Papers on Economic Activity Spring, 109-57. 
Case, Anne, and Deaton, Angus (2017). "Mortality and Morbidity in the $21^{\text {st }}$ Century," Brookings Papers on Economic Activity Spring, 397-443.

Chetty, Raj, Grusky, David, Hell, Maximilian, Hendren, Nathaniel, Manduca, Robert, and Narang, Jimmy (2017). “The Fading American Dream: Trends in Absolute Income Mobility Since 1940,” Science no. 356, 28 April, 398-406.

Corak, Miles (2013). “Income Inequality, Equality of Opportunity, and Intergenerational Mobility,” Journal of Economic Perspectives 27 (Summer, no. 3), 79-102.

Eppsteiner, Harris, Furman, Jason, and Powell, William (2017). “An Aging Population Explains Most - But Not All - of the Decline in the U.S. Labor Force Participation Rate Since 2007,” blog post, Peterson Institute of International Economics, July 7.

Fabricant, Solomon. (1961). “Basic Facts on Productivity Change,” Introduction to Kendrick (1961), pp. xxxv-lii.

Fernald, John G., Hall, Robert E., Stock, James H., and Watson, Mark W. (2017). “The Disappointing Recovery of Output After 2009,” Brookings Papers on Economic Activity Spring, 1-58.

Frey, Carl Benedikt, and Osborne, Michael A. (2017). “The Future of Employment: How Susceptible are Jobs to Computerisation?” Technological forecasting and social change 114, 254-280.

Frey, William H. (2017). “Foreign-born Growth Counters Trump’s Immigration Stereotypes,” Brookings the Avenue blog, October 2.

Goldin, Claudia, and Katz, Lawrence F. (2008). The Race between Education and Technology. Cambridge and London: The Belknap Press of Harvard University Press.

Gordon, Robert J. (2012) Macroeconomics. Boston: Addison-Wesley.

Gordon, Robert J. (2016). The Rise and Fall of American Growth: The U.S. Standard of Living Since the Civil War. Princeton and Oxford: Princeton University Press.

The Growing Gap in Life Expectancy by Income: Implications for Federal Programs and Policy Responses (2015). National Academies Press.

Guvenen, Fatih, Mataloni, Raymond J., Jr., Rassier, Dylan G, and Ruhl, Kim J. (2017). “Offshore Profit Shifting and Domestic Productivity Measurement,” NBER Working Paper 23324, April.

Herman, Juliana, Post, Sasha, and O’Halloran, Scott (2013). “The United States Is Far Behind Other Countries on Pre-K.” Downloaded from https://wwww.americanprogress.org/issues/education/reports/2013/05/02/62054 
Jones, Charles I., and Klenow, Peter J. (2016). “Beyond GDP? Welfare Across Countries and Time," American Economic Review 106 (September, no. 9), 2426-57.

Jorgenson, Dale W., Ho, Mun S., and Samuels, Jon D. (2017). "Educational Attainment and the Revival of U.S. Growth,” in Charles Hulten and Valerie Ramey, eds., Education, Skills, and Technical Change: Implications for Future U.S. GDP. Studies in Income and Wealth. Chicago and London: University of Chicago Press for NBER

Kendrick, John W. (1961). Productivity Trends in the United States. Princeton, NJ: Princeton University Press for NBER.

Krueger, Alan B. (2015). “The Great Utility of the Great Gatsby Curve,” Brookings Social Mobility Memos, May 19.

Leubsdorf, Ben (2017). “When Women Boost the Workforce,” Wall Street Journal, July 8, A2.

Lohr, Steve (2015). “Don’t Fear the Robots,” New York Times, October 25.

Mokyr, Joel (2018). “The Past and Future of Innovation: Lessons from Economic History,” Explorations in Economic History, forthcoming.

Moulton, Brent (2017). “The Measurement of Output, Prices, and Productivity: What's Changed Since the Boskin Commission,” presented at Brookings Workshop on Productivity Measurement, November.

Piketty, Thomas and Saez, Emmanuel (2003). "Income Inequality in the United States, 19131998,” Quarterly Journal of Economics 118, no. 1. 1-39.

Piketty, Thomas, Saez, Emmanuel, and Zucman, Gabriel (2016). “Distributional National Accounts: Methods and Estimates for the United States,” NBER Working Paper 22945, December.

Schwartz, Nelson D. (2017). “Workers Needed, but Drug Testing Takes a Toll,” New York Times, July 25, A1.

Solow, Robert M. (1957). “Technical Change and the Aggregate Production Function,” Review of Economics and Statistics 39 (no. 3), 312-20.

Selingo, Jeffrey J. (2017). “Blue Collar Redefined,” New York Times Education Life, February 5.

Syverson, Chad (2017). "Challenges to Mismeasurement Explanations for the US Productivity Slowdown,” Journal of Economic Perspectives 31 (Spring, no. 2), 165-86.

U. S. Bureau of the Census (2016), Income and Poverty in the United States 2015. Downloaded from: https://www.census.gov/content/dam/Census/library/publications/2016/demo/p60256.pdf 
Valletta, Robert G. (2016). "Recent Flattening in the Higher Education Wage Premium: Polarization, Skill Downgrading, or Both?” NBER Working Paper 22935, December.

Vedder, Richard, and Strehle, Justin (2017). “The Diminishing Returns of a College Degree,” Wall Street Journal, June 5, A10.

Vijg, Jan (2011). The American Technological Challenge: Stagnation and Decline in the 21 ${ }^{\text {st }}$ Century. New York: Algora Publishing.

Wasik, John F. (2017). "How Student Debt Is Snuffing Out Creative Sparks," New York Times, January 12 , B7. 